\title{
Перший досвід впровадження малоінвазивних технологій в кардіохірургічній практиці
}

Мета роботи: у статті розглянуто можливість використання малоінвазивних методів у кардіохірургії.

Ключові слова: малоінвазивні методи; хірургія; кардіохірургія; міксома; лапароскопія.

Первинні пухлини серця зустрічаються доволі рідко, їх виявляють лише 0,001-0,03 \% серед усієї серцевої патології. Міксоми ендокарду найбільш часто зустрічаються як доброякісні пухлини серця. Вони не мають патогномонічної клінічної картини, новоутворення невеликого або середнього розмірів можуть перебігати безсимптомно або виявлятися як знахідка при обстеженні пацієнтів з ознаками недостатньості кровообігу [1-5]. Рідко ускладнюються тромбоутворенням. Однак великі або гіганські міксоми можуть стати причиною розвитку життєво небезпечних станів, які потребують хірургічного лікування. Наводимо клінічний випадок спостереження хворого з міксомами лівого шлуночка серця.

\section{Опис клінічного випадку}

Хворий Л., 42 роки, перебував на стаціонарному лікуванні в кардіохірургічному відділенні Волинської обласної клінічної лікарні з 17.12.2018 p. по 8.01.2019 р.; при госпіталізації скаржився на слабкість в правих кінцівках, порушення мови, загальну слабкість.

В анамнезі ішемічний інсульт в басейні лівої СМА від 25.11.2018 р. Під час перебування на стаціонарному лікуванні в ЦРЛ із 25.11.2018р. по 07.12.2018 р. виявлено новоутворення лівого шлуночка. 2016 р. - лімфома Ходжкіна, склеро-ноду-

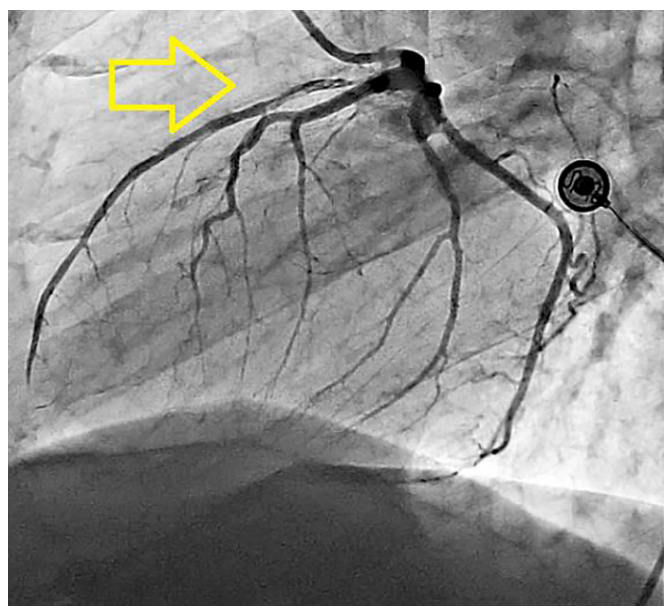

лярний варіант, виконано одну променеву терапію і 4 хіміотерапії.

При госпіталізації - стан пацієнта середньої тяжкості, дихання везикулярне, у всіх відділах, ЧДР14/хв, серцева діяльність ритмічна, пульс 60 уд./хв, ЧСС - 60/хв, АТ 130/80 мм рт. ст., живіт без особливостей. Периферичних набряків не виявлено. При обстеженні: ЕКГ - ритм синусовий, ЧСС - 61/хв, ЕхоКС - аорта 39/36 мм, ЛП - 46, КДР ЛШ - 51мм, КСР 33 мм, ФВ 63 \%, МШП - 10 мм, у базальному сегменті 11 мм, ЗСЛШ - 10 мм. Зони асинхронії не виявлено. АК: стулки ущільнені, непотовщені, в основі лівої коронарної стулки невеликий кальцинат $\Delta$ P 10 мм рт. ст. МК : стулки неущільнені, непотовщені. ПШ : 25 мм, скоротливість добра-індекс TAPSE 22 мм, регургітація: через МK 1, TK1, клапан ЛА 1. Ознаки ЛГ: відсутні (ст. тиск в ЛА 30 мм рт. ст.). ЛА 23 мм. Діастолічна функція ЛШ порушена. Примітки: в ділянці верхівки візуалізується мобільний утвір великих розмірів, неправильної форми, який кріпиться тонкою ніжкою завширшки до 4 мм та, ймовірно, до додаткових хорд ЛШ. Складається з двох фрагментів 1-21х10 мм, 2-27x17 мм (флотуючі з високим ризиком емболізації). Коронаро-вентрикулографія - стеноз 90 \% проксимального відділу передньої міжшлуночкової артерії (рис. 1).

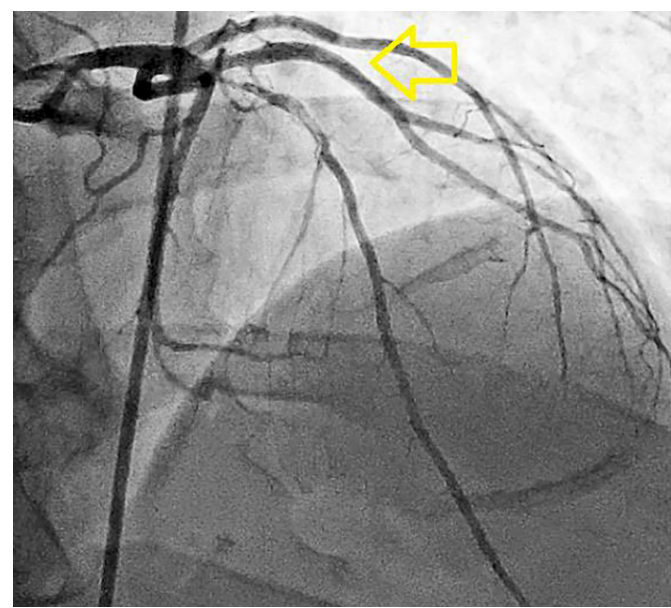

Рис. 1. Коронарогрфія, стеноз ПМША. 
Загальний аналіз крові, загальний аналіз сечі та біохімічний аналіз крові без патологічних змін. Коагулограма: ПІ - 100 \%, МНВ - 1.0 од., фібриноген - 3,78 г/л, група крові (B) III, $\mathrm{Rh}^{+}$. ФГДС - ерозивний гастрит, дуодено-гастральний рефлюкс. Різко виражений ерозивний бульбіт, уреазний тест - позитивний.

Діагноз: міксома лівого шлуночка, IXC, стенозуючий коронаросклероз, СН II аст. 2, ФК II.

Виконано операційне лікування.

Серединна стернотомія, перикардотомія. При ревізії серце не розширене. Проведено виділення мамарної артерії. Канюляція аорти та вушка правого передсердя, підключено АШК. Розпочато штучний кровообіг. Затискач на аорту, поперечна аортотомія, кардіоплегічна зупинка серця в коронарних артерій. Дренаж лівого передсердя. Доступом через аорту та аортальний клапан у лівий шлуночок введено лапароскоп (5 мм) та маніпулятори. При огляді в лівому шлуночку два патологічні утвори 35х40 мм і 10х20 мм, що, відповідно, кріпляться до латеральної стінки лівого шлуночка

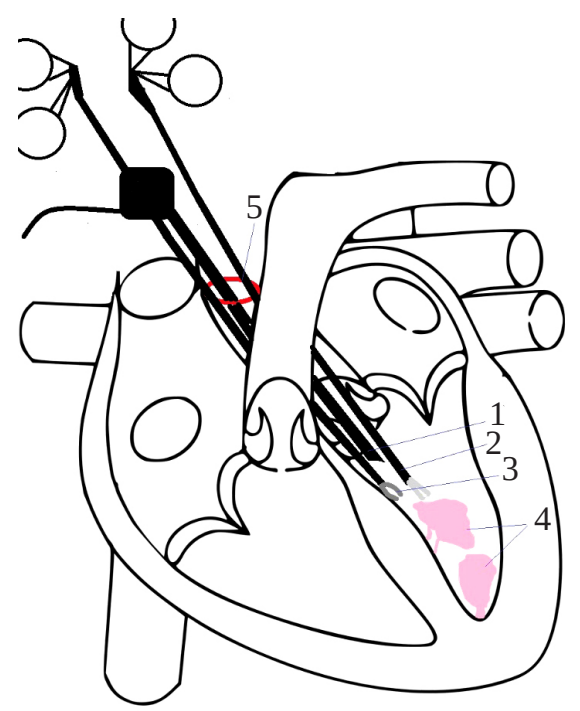

Рис. 2. Схема розміщення інструментів: 1 - ендоскоп 3 кутом $30^{\circ}$ (5 мм), 2 - ножиці Метценбаума (5 мм), 3 - затискач типу “мериленд” (5 мм), 4 - міксоми, 5 - доступ через аорту.

На 11 добу після операційного втручання хворого виписали в задовільному стані.

Міксоми $€$ повільнопрогресуючими захворюваннями. Хірургічне лікування міксом є загально- двома патологічними хордами та до верхівки серця ніжкою 4 мм у діаметрі. За допомогою ендоскопічних ножиць Метценбаума від'єднано утвори; ендоскопічними затискачами типу “мериленд” утвори видалено з порожнини серця через незмінений клапан. Гемостаз стійкий. В зоні верхівки проведено коагуляцію ніжки утвора. Мамарно-коронарне шунтування до передньої міжшлуночкової артерії; аорта ушита; проведено профілактику повітряної емболії. Знято затискач з аорти. Серцева діяльність відновилась за допомогою дефібриляції. Штучний кровообіг зупинено, проведено деканюляцію. Контроль на гемостаз - сухо (рис. 2).

На першу добу після операції пацієнта переведено на самостійне дихання і в подальшому переведений у відділення кардіохірургії ВОКЛ. Післяопераційний період минув без ускладнень, суб'єктивно у пацієта значне покращення самопочуття. Клініко-лабараторно без патологічних змін.

Заключення ПГД від 31.12.2018 р. - міксома з полями некрозу, поверхневим тромбоутворенням (рис. 3).

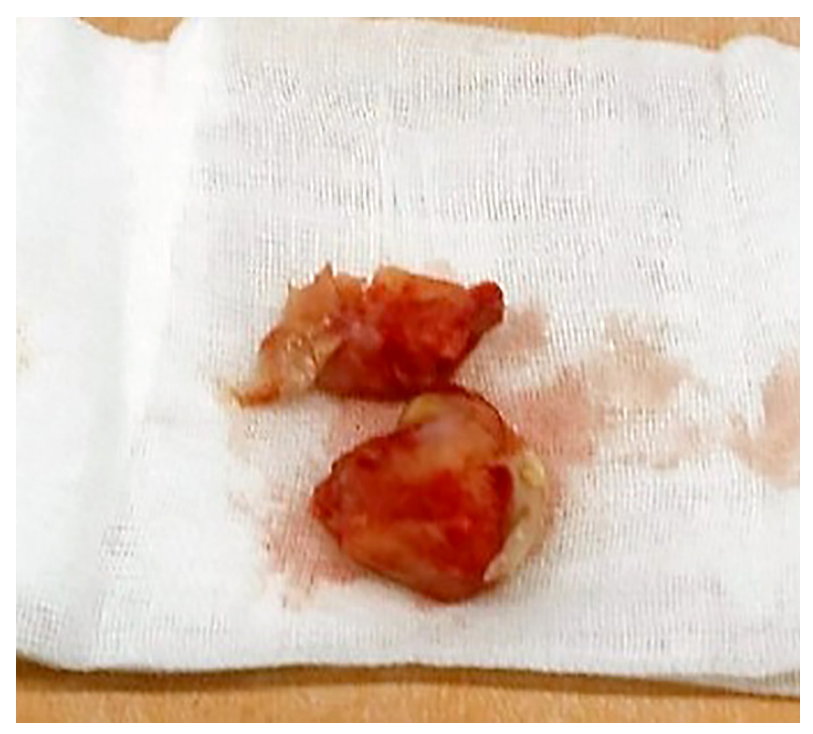

Рис. 3. Міксоми лівого шлуночка.

поширеною практикою. Впровадження малоінвазивних методик дає можливість значно скоротити час операційного втручання без пошкодження міокарда, що позитивно впливає на перебіг раннього та пізнього післяопераційного періоду, сприяє скороченню перебування хворого в стаціонарі. 


\section{СПИСОК ЛІТЕРАТУРИ}

1. Giant right atrial myxoma with pulmonary trunk dislodgement causing intermittent tricuspid obliteration and clinical manifestations of right heart failure / T. Y. Yang, J. P. Tsai, C. H. Chang [et al.] // Echocardiography. - 2011. - Vol. 28. - P. E183-E186.

2. Obstruction of the tricuspid valve orifice by a huge right atrial myxoma associated with the Carney complex: a case report / A. Affronti, I. Di Bella, P. Prontera [et al.] // J. Card. Surg. - 2010. - Vol. 25. - P. 674-676.

3. Leonard S. A heavy heart; A massive right atrial myxoma causing fatigue and short.- ness of breath / S. Leonard, J. Ryan

\section{REFERENCES}

1. Yang, T.Y., Tsai, J.P., Chang, C.H. (2011). Giant right atrial myxoma with pulmonary trunk dislodgement causing intermittent tricuspid obliteration and clinical manifestations of right heart failure. Echocardiography, 28, E183-E186.

2. Affronti, A., Di Bella, I., \& Prontera, P. (2010). Obstruction of the tricuspid valve orifice by a huge right atrial myxoma associated with the Carney complex: a case report. J. Card. Surg., 25, 674-676.

3. Leonard, S., \& Ryan, J.A. (2010). Heavy heart; A massive right atrial myxoma causing fatigue and shortness of breath. Ir. Med.
// Ir. Med. J. - 2010. - Vol. 103. - P. 83-84.

4. Primary and metastatic cardiac tumors: imaging characteristics, surgical treatment, and histopathological spectrum: a 10-yearexperience at a German heart center / T. Strecker, J. Rösch, M. Weyand, Abbas Agaimy // Cardiovascular Pathology. - 2012. - Vol. 21 (5). - P. 436-443.

5. A huge atrial myxoma causing severe double mitral lesions / D. Dobarro, C. Gómez-Rubín Mdel, A. Sánchez-Re-calde [et al.] // Heart Lung Circ. - 2009. - Vol. 18. - P. 131-132.

\section{J., 103, 83-84.}

4. Strecker, T., Rösch, J., Weyand, M., \& Abbas Agaimy (2012). Primary and metastatic cardiac tumors: imaging characteristics, surgical treatment, and histopathological spectrum: a 10-yearexperience at a German heart center. Cardiovascular Pathology, 21 (5), 436-443.

5. Dobarro, D., Gómez-Rubín Mdel, C., \& Sánchez-Re-calde, A. (2009). A huge atrial myxoma causing severe double mitral lesions. Heart Lung Circ., 18, 131-132.

Отримано 11.01.2019

\section{FIRST EXPERIENCE OF IMPLEMENTATION OF MINI-INVASIVE TECHNOLOGY IN CARDIAC SURGERY}

The aim of the work: the article adduces a possibility of using mini-invasive technology in cardiac surgery.

Key words: mini-invasive; surgery; cardiac; myxoma; laparoscopy.

В. В. ПЕЦЕНТИЙ, Н. М. ГАЛЕЙ, А. Ю. ТАРАНЕЦ, И. П. МАРЧУК

Волынская областная клиническая больница

\section{ПЕРВЫЙ ОПЫТ ВВЕДЕНИЯ МАЛОИНВАЗИВНЫХ ТЕХНОЛОГИЙ В КАРДИОХИРУРГИЧЕСКОЙ ПІРАКТИКЕ}

Цель работы: в статье рассмотрено возможность использования малоинвазивных методов в кардиохирургии.

Ключевые слова: малоинвазивные методы; хирургия; кардиохирургия; миксома; лапароскопия. 